\title{
67
}

\section{IMPLEMENTASI KEBIJAKAN KETENAGAKERJAAN DI KABUPATEN SUMEDANG}

\author{
Oleh: \\ Muhammad Indra Andityaputra, Budhi Wibhawa, \& Muhammad Fedryansyah \\ Email: \\ Andityohumble@gmail.com; budhiwibhawa@gmail.com; \\ fedry_cons@yahoo.com
}

\begin{abstract}
Abstrak
Tujuan penelitian ini adalah menganalisis hasil penelitian mengenai implementasi kebijakan ketenagakerjaan di Indonesia. Penelitian ini dilakukan berdasarkan pengamatan dan wawancara awal yang penulis lakukan dengan unit-unit yang terkait dengan pelaksanaan penerapan kebijakan ketenagakerjaan di Indonesia, dimana penulis menemukan indikasi mengenai masih kurang optimalnya penerapan kebijakan ketenagakerjaan di Indonesia. Hal ini juga memperkuat dengan data mengenai belum tercapainya target kerja Dinas Sosial Tenaga Kerja dan masih banyaknya jumlah pengangguran yang tidak dapat memiliki kesempatan kerja di Sumedang. Penulis menduga bahwa masih kurang optimalnya penyerapan tenaga kerja lokal yang berhubungan erat dengan kurang maksimalnya implementasi kebijakan mengenai ketenagakerjaan.

Hipotesis yang diajukan oleh penulis adalah "Jika diimplementasikan kebijakan Dinas Sosial Tenaga Kerja tentang ketenagakerjaan berdasarkan syarat-syarat pelaksanaan kebijakan, maka penyerapan tenaga kerja lokal di Indonesia akan meningkat". Landasan teori adalah model proses implementasi kebijakan Adam Jamrozik.

Kata kunci : penyerapan tenaga kerja lokal, penerapan kebijakan ketenagakerjaan

Abstract

The purpose of this study was to analyze the results of research on the implementation of employment policy in Sumedang. This study is based on observations and interviews conducted by the author beginning with the units associated with the implementation of the employment policy in Sumedang, where the authors found indications are lacking regarding optimal implementation of employment policy in Sumedang. It also reinforces the data on the achievement of targets not working Social Service Workers and still the number of unemployed who can not have job opportunities in Sumedang. The authors suspect that is still less than optimal local employment which are closely related to maximal implementation of employment policy.

The hypothesis proposed by the authors is "If the policy is implemented Social Service Workers on employment under the terms of the policy implementation, the local employment in Sumedang will increase". The foundation of the theory used to test the hypothesis is a model Adam Jamrozik policy implementation process.
\end{abstract}

Keywords : local employment, employment policies

\section{PENDAHULUAN}


Masalah pengangguran masih menjadi masalah utama dalam pembangunan. Khususnya di Indonesia, masalah pengangguran merupakan masalah klasik yang sudah lama belum terselesaikan. Di tahun 2013, jumlah pengangguran nasional mengalami kenaikan dibandingkan tahun sebelumnya. Secara umum, tingkat pengangguran dan kemiskinan di Indonesia masih tinggi. Persentasenya masih di atas rata-rata provinsi dan pusat. Kemudian persentase tingkat kemiskinan dan pengangguran di provinsi dan pusat rata-rata terbilang rendah. Misalnya dalam Kabupaten Sumedang. Dengan tingkat pengangguran yang besar, Kabupaten Sumedang menghasilkan jumlah angkatan kerja yang hanya sedikit tahunnya.

Untuk menangani masalah pengangguran di Kabupaten Sumedang tersebut, sejak tahun 2012, pemerintah daerah Kabupaten Sumedang mengeluarkan kebijakan penanganan masalah pengangguran. Kebijakan tersebut tertuang dalam Peraturan Daerah Kabupaten Sumedang Nomor 41 tahun 2001 tentang organisasi dan tata kerja unit pelaksana teknis dinas Balai Latihan Kerja Usaha Kecil dan Menengah. Kebijakan ini disusun berdasarkan pertimbangan bahwa dalam rangka pelaksanaan pembangunan bidang ekonomi, sesuai dengan Pasal 2 Perda Kabupaten Sumedang bahwa perlu ditetapkannya organisasi dan tata kerja terhadap Balai Latihan Kerja Usaha Kecil dan Menengah pada Dinas Tenaga Kerja.

Dinas Sosial dan Ketenagakerjaan Kabupaten Sumedang sebagai salah satu pihak yang memiliki tanggung jawab dalam melaksanakan urusan pemerintahan dalam rangka pelaksanaan sebagian tugas Bupati khususnya di bidang ketenagakerjaan. Pembentukan struktural pada Dinas Sosial dan Ketenagakerjaan dimaksud diarahkan untuk menyelengggarakan urusan Pemerintahan Daerah Kabupaten Sumedang yang efektif, efisien dan akuntabel.

Pembentukan dinas ini bertujuan untuk menyelesaikan masalah ketenagakerjaan di level daerah khususnya di Kabupaten Sumedang. Adapun dinas ini memiliki wewenang dalam memberikan pelayanan sosial yang bentuknya pemberdayaan, perlindungan dan jaminan sosial dalam konteks secara umum. Sementara secara khusus dalam hal ketenagakerjaan, lembaga mengeluarkan kebijakan sosial berupa program Balai Latihan Kerja untuk menangani masalah terkait kemiskinan, keterlantaran, ketunasosialan, eksploitasi dan diskriminasi hak warga Negara dalam mendapatkan pekerjaan.

\section{Perlindungan Tenaga Kerja}

Dinas Sosial dan Tenaga Kerja Kabupaten Sumedang sebagai salah satu perangkat daerah mewadahi lembaga yang membantu Bupati dalam menyusun kebijakan sosial terkait ketenagakerjaan serta pihak yang berperan sebagai penunjang pelayanan masyarakat yang memiliki peranan yang strategis dalam menunjang pembangunan perekonomian di Kabupaten Sumedang. Selain itu, adanya kebijakan tersebut diharapkan dapat mengatur penciptaan lapangan pekerjaan bagi para masyarakat lokal Sumedang dan menangani permasalahan dalam hal ketenagakerjaan. Dalam hal ini, masalah ketenagakerjaan bersifat kompleks dikarenakan semakin terbatasnya lapangan kerja dan jumlah pencari kerja yang semakin bertambah.

Oleh karena itu, Dinas Sosial dan Tenaga Kerja dalam hal ini sebagai unsur pembantu Bupati menciptakan suatu program dalam menangani masalah ketenagakerjaan yaitu Unit Pelaksana Teknis Balai Latihan kerja (UPT BLK). BLK merupakan suatu bentuk kebijakan sosial berupa program yang dibawahi oleh Bupati kepada Dinas Sosial dan Tenaga Kerja. Pembentukan tersebut untuk meningkatkan kualitas tenaga kerja dengan dibekali keterampilan. Dalam hal ini, keterampilan yang dimiliki oleh para tenaga kerja merupakan modal dasar yang sangat penting dalam upaya meningkatkan daya saing mereka untuk dapat masuk dalam bursa pencarian kerja potensial, sehingga memiliki peluang besar diterima sebagai tenaga kerja diperusahaan-perusahaaan. Adapun gagasan ini muncul dari para Satuan Kerja Perangkat Daerah di Kabupaten Sumedang yang dilaksanakan oleh Dinas Sosial dan Tenaga Kerja yang memandang penting adanya standarisasi pelaksanaan 
pengembangan masyarakat dan menciptakan para calon pencari kerja yang berkualitas sesuai dengan kebutuhan industri riil.

Dalam rangka peningkatan kualitas tenaga kerja, Dinas Sosial dan Tenaga Kerja merancang program yang berpedoman pada tiga pilar utama yaitu Pelatihan, Sertifikasi dan Penempatan. Melalui tiga pilar tersebut, diharapkan dapat menghasilkan output yang maksimal sehingga dampak dari masalah ketenagakerjaan dapat dirasakan langsung oleh oleh masyarakat terutama para pencari kerja. Prinsip dasar pelatihan kerja yang dilaksanakan Unit Pelaksana Teknis Balai Latihan Kerja (UPT BLK) beserta Seksi Pelatihan dan Sertifikasi selama ini antara lain berorientasi kepada kebutuhan pasar kerja dan pengembangan SDM serta berbasis pada kompetensi kerja. Adapun target sasaran pesertanya adalah masyarakat secara umum terutama pencari kerja dan kelompok usaha, namun khusus pelatihan dan pembinaan untuk lembaga pelatihan keterampilan swasta dalam hal ini merupakan kewenanangan dari Seksi Pelatihan dan Sertifikasi.

Secara khusus di kawasan Jatinangor, situasi yang terjadi yaitu perubahan dalam struktur pekerjaan. Sektor pertanian kini sudah tidak lagi mendominasi mayoritas profesi pekerjaan. Kini secara revolusi, telah terjadi peralihan menjadi sektor non pertanian. Adapun profesi dari sektor pertanian disini yaitu buruh/karyawan, PNS/TNI serta wirausaha. Penduduk dengan mata pencahariaan yang telah disebutkan merupakan profesi yang mayoritas dipilih oleh masyarakat. Sementara penduduk di Kecamatan Jatinangor yang meliputi desa-desa yang masih banyak penganggur atau bekerja dengan pola dan penghasilan yang tidak jelas.

Secara geografis, jatinangor termasuk kawasan strategis yang menuju ke area perkotaan karena wilayahnya yang strategis dalam mendirikan atau memperluas lapangan pekerjaan. Hal ini dapat dibuktikan dengan adanya lapangan pekerjaan seperti foto kopi, toko, rental komputer, wartel, rumah makan, hotel, ojek, laundry dan lain-lain. Berdasarkan studi penelitian Theresia (1998) menunjukkan bahwa keberadaan empat perguruan tinggi di Jatinangor mempengaruhi banyaknya lapangan pekerjaan yang ada.

Mardianta (2001) menunjukkan bahwa kegiatan ekonomi seperti kegiatan penyerapan tenaga kerja lebih banyak dilakukan oleh pendatang daripada penduduk lokal. Sementara penduduk di Kecamatan Jatinangor yang meliputi beberapa desa termasuk yang masih banyak penganggur atau bekerja dengan pola dan penghasilan yang tidak jelas. Pendidikan para pekerja kebanyakan mereka lulusan SD. Hal ini dapat membuktikan bahwa kawasan Jatinangor menghadapi dua persoalan yaitu pengangguran dan kualitas tenaga kerja yang rendah.

\section{BAGIAN ISI}

Implementasi kebijakan program ketenagakerjaan di Indonesia, khususnya Kabupaten Sumedang perlu memperhatikan Goals yang didapat. Menurut Stone (2002, hal. 35-108) menyatakan ada beberapa kategori yang harus ada dalam menentukan Goals, yaitu keadilan (equity), efisien (efficiency), keamanan (security), dan kebebasan (liberty). Keadilan/Equity adalah bagaimana cara melihat distribusi kebijakan program Balai Latihan Kerja (BLK) dilakukan secara merata. Efisiensi/Efficiency adalah bagaimana cara melihat penggunaan sumber daya yang tepat dan sesuai kebutuhan. Keamanan/Security adalah bagaimana cara melihat pemberian layanan jaminan sosial/jaring pengaman sosial khusus bagi para pencari kerja khusus pada warga lokal. Kebebasan/Liberty adalah cara melihat bagaimana memberikan kesempatan kerja terhadap warga lokal Kabupaten Sumedang. Kebijakan program ketenagakerjaan harus memperhatikan empat kategori tersebut, untuk melihat bagaimana goals sudah tercapai atau belum tercapai dari kebijakan program ketenagakerjaan di Kabupaten Sumedang. Oleh karena itu perlu diadakannya penelitian tentang implementasi kebijakan tenega kerja ditinjau melalui setting goals terkait permasalahan ketidaksesuaian antara kebijakan dengan kondisi nyata dilapangan.

Implementasi mengacu pada kepada sistem pelaksanaan perangkat-perangkat berupa penetapan oleh penyusun kebijakan, perangkat tindakan yang paling tepat untuk mencapai objectives. 
Objectives dimaksud disini yaitu tindak lanjut penyerapan tenaga kerja lokal di Kabupaten Sumedang dan pemenuhan kebutuhan hak-hak ekonomi calon tenaga kerja lokal. Perangkat tindakan alternatif yang dapat dipertimbangkan adalah penyediaan lapangan tenaga kerja lokal Kabupaten Sumedang sesuai dengan penyerapan tenaga kerja lokal yang dilakukan oleh Pemerintah daerah yang hanya bertujuan untuk menyelesaikan masalah ketenagakerjaan. Sesuai dengan kebijakan peraturan daerah Kabupaten Sumedang Nomor 8 Tahun 2008 yang dirubah dengan Nomor 2 Tahun 2010 serta dalam Pasal tentang ketenagakerjaan menjelaskan bahwa Dinas Sosial Tenaga Kerja selaku perangkat daerah telah melakukan perumusan kebijakan teknis di bidang kesejahteraan sosial, bidang pelayanan sosial, bidang pelatihan dan penempatan tenaga kerja, serta bidang perlindungan tenaga kerja. Kemudian juga dapat dilakukan pemilihan alternatif lain yang akan menuntut penyusun kebijakan untuk mempersiapkan perangkat tindakan alternatif yang dirancang untuk melaksanakan setiap keputusan. Hal ini tentu menuntuk pihak yang memiliki kepentingan dalam merumuskan kebijakan sekaligus dapat menyelenggarakan urusan pemerintahan dan pelaksanaan pelayanan umum di bidang sosial dan tenaga kerja.

Kebijakan dipandang sebagai landasan dalam praktik pekerjaan sosial (Thompson). Kebijakan merupakan penghubung antara perundang-undangan dengan praktik. Kebijakan sosial merujuk kepada kebijakan yang dirancang untuk merespon masalah sosial dan disiplin akademik yang mempelajari kebijakan-kebijakan tersebut, perancangan kebijakan dan dampak dari kebijakan tersebut.

Kebijakan sosial dikemukakan oleh Jamrozik sebagai sebuah mekanisme untuk mengalokasikan sumberdaya yang ada pada masyarakat dengan tujuan untuk mencapai outcome tertentu sesuai harapan nilai-nilai dominan masyarakat serta tujuan dan sasaran kebijakan yang telah ditentukan.

"social policy is a mechanism for the allocation of a society's resources for the purpose of achieving certain outcomes that bring to fruition the society's dominant values and corresponding objectives and goals".

Lebih lanjut, dijelaskan oleh Jamrozik bawa kebijakan sosial pada hakekatnya berurusan dengan pengaturan hubungan sosial yang bertujuan untuk menegaskan nilai-nilai dan kepentingan tertentu. Hal tersebut dilakukan melalui implementasi pendekatan yang sesuai yang didesain untuk mencapai hasil yang diharapkan.

Berbeda dengan Jamrozik, Midgley and Livermore membagi kebijakan sosial kedalam dua aspek. Pertama kebijakan sosial dipahami sebagai kebijakan dan program yang dijalankan oleh pemerintah, yang didesain untuk meningkatkan kesejahteraan masyarakat atau meningkatkan harkat manusia. Kedua, kebijakan sosial dipahami sebagai kegiatan akademik yang mencakup deskripsi, eksplanasi, dan evaluasi terhadap kebijakan sosial.

Pandangan Midgley tersebut diperkuat oleh pendapat Deacon yang menyatakan bahwa kebijakan sosial sebagai suatu kajian dan analisis seringkali dipandang tidak memiliki hubungan yang erat dengan ilmu sosial lainnya seperti ilmu ekonomi, ilmu sosiologi, dan ilmu politik. Namun, pandangan tersebut terbantahkan ketika melihat pada manfaat dari jaminan sosial atau administrasi dari sistem layanan kesehatan. Pendukung kajian kebijakan sosial justru melihat bahwa kajian tersebut memiliki hubungan yang erat dengan ilmu sosial lainnya ketika mewujudkan kesejahteraan sosial masyarakat, dengan menggunakan kerangka kerja analitisnya dan penekanan pada isu keadilan sosial dan kebutuhan manusia.

Bahasan dan kajian kebijakan sosial dapat dilihat dari beragam cara dan saling mengikat satu dengan lainnya. Pada satu sisi, ini merupakan kebijakan dan praktik dalam menyelenggarakan layanan kesehatan, jaminan sosial atau perlindungan sosial, pendidikan, dan perumahan. Sementara kajian kebijakan sosial ini dianggap sebagai bagian dari sektor kebijakan yang dikembangkan di negara-negara kesejahteraan, kajian ini mulai tumbuh dan diterapkan di negara-negara yang sedang berkembang (Hall and Midgley \& Mkandawire). Ketika diterapkan di negara-negara tersebut, perlu 
dilakukan modifikasi untuk mengubah kerangka berpikir dan merangkul masyarakat miskin sehingga kesejahteraan sosial dapat diwujudkan (Gough and Woods). Karena itu kajian kebijakan sosial merupakan bagian dari kajian negara kesejahteraan dan kajian pembangunan pada pengembangan negara kesejahteraan. Pemisahan kedua konsep tersebut akan mengaburkan tentang pemahaman kajian pembangunan di negara kesejahteraan serta kebijakan sosial dalam konteks pembangunan yang hanya fokus pada kemiskinan, akibatnya akan melupakan isu keadilan dan universalisme.

Pendekatan lainnya dalam kajian kebijakan sosial adalah dilihat dari isu yang menjadi perhatian dalam peningkatan kesejahteraan sosial di suatu negara. Dengan kata lain, kebijakan sosial sebagai kajian adalah apa yang dilakukan oleh sarjana kebijakan sosial. Sebuah standar teks kebijakan sosial (Alcock) disusun berdasarkan konsep yang menjadi perhatian dari analis kebijakan sosial yaitu 'kebutuhan sosial dan masalah sosial', 'persamaan hak dan keadilan sosial', 'efisiensi, keadilan, dan pilihan', 'altruisme, hubungan timbal balik, kewajiban', dan 'pembagian, perbedaan, dan ekslusi' .

Lebih lanjut, Chambers and Wedel menjelaskan keterkaitan antara pekerjaan sosial dengan analisis kebijakan sosial yang dilihat berdasarkan kriteria nilai (value-based criteria). Analisis kebijakan sosial dapat dibagi menjadi tiga tipe yaitu value-analytic of policy analysis, valuecommitted of policy analysis, dan value-critical methods of policy analysis. Chambers memberikan gambaran mengenai kasus pekerja di lahan pertanian yang menggunakan pestisida atau di industri nuklir. Dari kasus tersebut, yang menjadi pertimbangan adalah bukan seberapa besar kompensasi (gaji dan asuransi) yang harus diterima oleh para pekerja tersebut, melainkan bagaiman industri yang beresiko tinggi dapat diijinkan beroperasi jika aktifitas produksi mereka sangat beresiko yang membuat semua rancangan sistem kompensasi akhirnya tidak berguna. Kemudian, Chambers juga memaparkan bahwa pekerjaan sosial dan praktisi pelayanan sosial akan menggunakan value-critical methods of policy analysis, yakni ketika menetapkan kriteria tentang "kebaikan" dalam suatu kebijakan sosial dan program layanan sosial. Value critical analysis akan membantu memecahkan masalah kebijakan melalui penggunaan kriteria berdasarkan nilai (value-based criteria). Chambers juga menyatakan bahwa pekerjaan sosial dalam praktiknya menggunakan banyak perspektif mengenai kondisi manusia, maka pendekatan value-critical lebih tepat digunakan untuk pekerjaan sosial karena pendekatan tersebut juga menekankan pada multipel perspektif dalam melihat kondisi manusia.

\section{Teori Kebijakan Sosial}

Adam Jamrozik mendefinisikan kebijakan sosial sebagai "mekanisme untuk alokasi masyarakat sebagai sumber daya yang bertujuan mencapai hasil tertentu yang membawa hasil nilainilai dominan dalam masyarakat dan menyesuaikan sasaran dan tujuan. Dalam prakteknya, secara khusus tujuan dan sasaran, dan nilai-nilai yang mendasari peran pemerintah dari pihak-pihak yang berkuasa. Setiap kebijakan tersebut dapat mencerminkan nilai-nilai mendalam dominan dari masyarakat yang melampaui perpecahan politik yang dicontohkan oleh partai politik. Mungkin kebijakan yang dirancang untuk mengubah nilai-nilai yang dominan dalam masyarakat atau untuk menegaskan kembali dan memperkuat nilai-nilai tersebut. Selain itu, esensi dari kebijakan sosial yaitu

\footnotetext{
"Social Policy is concerned with the regulation of social relationships for the purpose of affirming certain values and interests through the implementation of appropriate means designed to achieve corresponding ends. "
}

Sebagai suatu produk, kebijakan sosial mencakup perundang-undangan dan perintah eksekutif, penafsiran keputusan kehakiman, keputusan administratif, dan program yang sesungguhnya serta pelayanan. Kebijakan sosial dapat menghasilkan suatu hukum yang baru. Produk kebijakan sosial berupa program atau putusan pengadilan. Sebagai kebijakan administratif, kebijakan sosial dapat menjelaskan sistem klasifikasi tenaga kerja atau penetapan dalam menjadi staf 
professional dengan para agen. Produk kebijakan sosial memerlukan perencanaan yang khusus dalam implementasi. Setelah kebijakan sosial dalam penerapan di tempat dan pengumpulan dana agar implementasi program menjadi tersedia.

Pekerja sosial membuat keputusan tentang cara memberikan pelayanan. Pekerja sosial merancang program dalam melaksanakan tujuan kebijakan untuk mempengaruhi harapan perubahan. Pekerja sosial menghasilkan kebijakan administratif secara jelas yang menegaskan peran, tugas, dan menunjukkan pekerjaan personil agen. Pekerja sosial merumuskan kebijakan dan pedoman prosedur untuk menyampaikan harapan, tanggung jawab, dan ukuran hasil. Dengan menerapkan kebijakan sosial dalam satu sistem sosial yang mengharuskan adanya aturan dan penerapan hubungan keputusan kebijakan terhadap sistem lain yang baik pula.

Kabupaten Sumedang memiliki potensi perindustrian yang cukup besar. Sebagai kawasan yang terus berkembang dan memiliki interaksi sosial dan ekonomi yang sangat fungsional, Kabupaten Sumedang memang seharusnya memiliki agenda yang terintegrasi dalam mengantisipasi berbagai masalah yang ada. Dalam hal ini masalah yang dimaksud ialah masalah ketenagakerjaan. Masalah ketenagakerjaan telah menjadi masalah yang sangat kompleks. Namun, jika dilihat dari sudut pandang lebih, semua masalah ketenagakerjaan berhulu pada kesempatan kerja.

Secara lebih spesifik, isu atau masalah ketenagakerjaan ini juga seringkali dihubungkan dengan besarnya selisih negatif antara tenaga kerja lokal yang tersedia dengan kemampuan penyerapan bursa pasar kerja yang ada. Hal tersebut terjadi karena adanya kesenjangan antara kebutuhan tenaga kerja dengan ketersediaan tenaga kerja yang sesuai dengan kualifikasi dan kompetensi yang dibutuhkan. Pihak perusahaan tentunya menginginkan tenaga kerja yang memiliki kualifikasi dan kompetensi yang sesuai dengan kebutuhan operasional perusahaan. Namun, ketersediaan tenaga kerja di Sumedang dirasakan masih belum memiliki kualifikasi dan kompetensi yang sesuai.

Pertambahan angkatan kerja harus diimbangi dengan investasi yang dapat menciptakan kesempatan kerja. Dengan demikian, dapat menyerap pertambahan angkatan kerja. Dalam ilmu ekonomi, kesempatan kerja berarti peluang atau keadaan yang menunjukkan tersedianya lapangan pekerjaan sehingga semua orang yang bersedia dan sanggup bekerja dalam proses produksi dapat memperoleh pekerjaan sesuai dengan keahlian, keterampilan dan bakatnya masing-masing. Sehingga dapat disimpulkan pula bahwa kesempatan kerja (demand for labour) sebagai suatu keadaan yang menggambarkan/ketersediaan pekerjaan (lapangan kerja untuk diisi oleh para pencari kerja).

Pengangguran dapat memberikan efek yang sangat buruk. Dalam negara Kesejahteraan, pengangguran ini mengurangi jumlah pendapatan yang keluarga atau satu orang terima. Pengangguran jangka pendek, khususnya ketika satu orang menerima kompensasi pengangguran, mungkin hanya memiliki konsekuensi yang kecil. Sementara pengangguran jangka panjang menimbulkan masalah yang panjang. Pengangguran ini memimpin ke arah isolasi yang ekstrem. Pengangguran jangka panjang disini menyebabkan perubahan sifat yang berlangsung setelah tidak bekerja lagi. Misalnya seseorang yang telah dipecat diinterpretasikan sebagai pengangguran yang tidak memiliki kemampuan dan tidak bernilai. Akibatnya, harga diri menjadi turun, depresi dan merasa terasingkan dari masyarakat. Bahkan ketika mereka mendapatkan pekerjaan baru, mereka tidak bisa memulihkan harga dirinya secara penuh.

Asumsi tingginya angka pengangguran di dunia yang semakin banyak dan kompleks. Ketika masyarakat memiliki kesempatan kerja penuh, akan selalu ada beberapa orang yang mampu bekerja tetapi untuk sementara menganggur karena beberapa orang akan berganti profesi. Secara umum, kebanyakan negara mempertimbangkan pekerjaan penuh untuk tetap ada ketika angka pengangguran termasuk rendah dari kekuatan pekerja. Lebih banyak terdapat kekuatan pekerja daripada lowongan pekerjaan. Secara otomatis, banyak industri yang sudah mengurangi angka pekerja yang diperlukan dan membuat pekerjaan tertentu. 
Tingginya angka pengangguran juga disebabkan oleh masalah pengangguran struktural. Angka pengangguran yang semakin besar terjadi, karena orang yang menganggur tidak terlatih untuk posisi yang terbuka. Baru-baru ini, banyak pekerjaan kasar yang sudah tidak kelihatan (dalam industri besi). Ketika pekerjaan dengan keahlian yang tinggi sudah dibuka di tempat lain (misalnya lapangan pekerjaan komputer). Orang-orang dilatih untuk menempati posisinya saat ini, sementara tenaga kerja membutuhkan peningkatan ekonomi yang signifikan. Selain itu, akan terus menerus terjadi ketidakharmonisan antara keterampilan yang dibutuhkan untuk posisi yang kosong dan keterampilan yang dimiliki oleh orang-orang pengangguran..

Penciptaan program BLK yaitu untuk menangani masalah ketenagakerjaan dan untuk menningkatkan kualitas tenaga kerja dengan dibekali keterampilan. Adapun pelaksanaan BLK mengacu pada pelatihan berbasis kompetensi, pelatihan berbasis masyarakat, pelatihan kewirausahaan, dan program pemagangan yang bekerjasama dengan Dinas Tenaga Kerja dan Transmigrasi Provinsi Jawa Barat. Jenis pelatihan yang telah disebutkan merupakan jenis pelatihan yang paling banyak menyerap tenaga kerja lokal baik di sektor formal maupun informal. Dengan disertai prosedur yang telah dilakukan dalam menjaring peserta pelatihan diharapkan mereka betulbetul memiliki keterampilan dan keahlian yang optimal. Pada pelaksanaannya, pelatihan berbasis masyarakat lebih banyak melibatkan para pencari kerja yang membutuhkan pelatihan keterampilan baik dari perorangan maupun kelompok. Dalam hal ini, peran aktif Dinas Sosial dan Tenaga Kerja diperlukan dalam mengarahkan mereka sehingga dapat memiliki keahliannya sesuai dengan keahlian yang dibutuhkan oleh dunia usaha dengan harapan mereka dapat memasuki pasar kerja.

Penelitian ini bermaksud untuk melihat hasil dari aplikasi kebijakan ketenagakerjaan di Kab. Sumedang. Selain itu untuk mengetahui sejauh mana aplikasi program Balai Latihan Kerja berjalan, maka perlu adanya peninjauan dari tujuan sasaran/goals program tersebut. Dengan peninjauan goals pada program Balai Latihan Kerja dapat diketahui tingkat keberhasilan dari aplikasi kebijakan program tersebut, apakah dinyatakan berhasil atau gagal. Aplikasi kebijakan ketenagakerjaan yang dilakukan akan diketahui atau tidaknya apabila dilakukan peninjauan goals. Selain untuk mengetahui tingkat keberhasilan program yang telah dilaksanakan, tinjauan terhadap goals juga dapat digunakan untuk mengetahui kelebihan, kekurangan, dan masalah yang ditemukan. Keadaan ini dapat membantu pemerintah untuk menemukan solusi yang tepat dan dapat digunakan untuk merancang program yang akan dijalankan selanjutnya.

Peninjauan goals yang dilakukan dalam penelitian ini terfokus kepada penerapan kebijakan ketenagakerjaan Kabupaten Sumedang, menurut Stone yang meliputi: Keadilan/Equity, Efisiensi/Efficiency, Keamanan/Security, Kebebasan/Liberty.

Keadilan/Equity adalah bagaimana Dinas Sosial dan Tenaga Kerja Kabupaten Sumedang menerapkan kebijakan ketenagakerjaan dan dilakukan secara optimal, dengan mempertimbangkan pula kebutuhan di dalamnya dan apa-apa saja yang diperoleh dari sasaran kebijakan yang dinilai telah mencukupi.

Efisiensi/Efficiency; berhubungan dengan bagaimana Dinas Sosial dan Tenaga Kerja Kab. Sumedang mengalokasikan sumber dayanya untuk mendapatkan hasil yang optimal dalam menerapkan kebijakan ketenagakerjaan. Pada dasarnya adanya hubungan dengan: apa yang mesti dilakukan, dan bagaimana metode yang tepat.

Keamanan/Security; berhubungan dengan pemerintah Kab. Sumedang khususnya Dinas Sosial dan Tenaga Kerja Kab. Sumedang menciptakan keamanan dalam memberikan pelayanan sosial. Hal ini dilakukan untuk memberikan apa-apa saja jenis kebutuhan yang sesuai untuk memenuhi kebutuhan pada isu jaminan sosial.

Kebebasan/Liberty; berhubungan dengan bagaimana pemerintah Kab. Sumedang khususnya Dinas Sosial dan Tenaga Kerja Kab. Sumedang menjamin kebebasan secara individual maupun kolektif. Kebebasan bertindak dari setiap individu di padu dengan sebuah konsep perlindungan diri, dan mencegah kerugian pada orang lain. 


\section{PENUTUP}

Permasalahan kebijakan yang mengatur penyerapan tenaga kerja lokal, pelatihan kerja berbasis kompetensi, masyarakat dan kewirausahaan, pelayanan penempatan kerja serta pengurangan tingkat pengangguran. Produk kebijakan untuk menangani permasalahan ketenagakerjaan sudah ada tetapi masalahnya pelaksanaannya tidak dapat menjangkau semua sasaran. Hal ini berdampak pada peningkatan tingkat pengangguran dan tingkat inflasi. Dinas Sosial dan Ketenagakerjaan Kabupaten Sumedang sebagai pihak yang memiliki tanggung jawab dalam melaksanakan urusan pemerintahan dalam rangka pelaksanaan sebagian tugas Bupati khususnya di bidang ketenagakerjaan. Diperkirakan upaya mencari solusi penyelesaian masalah kebijakan ketenagakerjaan Sumedang tahun 2014-2017 akan lebih efektif untuk mencapai target pencapaian pembangunan daerah yang bertumpu pada program pembangunan daerah lengkap dengan sistem pendanaan serta penurunan tingkat pengangguran dan tingkat inflasi.

Agar masalah kebijakan ketenagakerjaan dapat mencapai penyelesaian yang memenuhi harapan pihak pekerja dan pengusaha, diperlukan peran pemerintah sebagai regulator dan mediator yang adil untuk mengembalikan fungsi kebijakan ketenagakerjaan yang sebenarnya

\section{DAFTAR RUJUKAN}

Bappeda Kab. Sumedang. 2009. Laporan Akhir Studi Kelayakan Kawasan Jatinangor Sebagai Kawasan Perkotaan Sumedang.

Depnakertrans. 1998-2005. Depnakertrans situasi tenaga kerja dan kesempatan kerja di Sumedang. Jakarta: Depnakertrans RI.

Graziano A M, Raulin M L. 1989. Research methods: a process of inquiry. New York: Harper Collins Publishers.

Jamrozik, Adam. 2009. Social Policy In The Post - Welfare state : Australian Society In The Changing World.

Midgley, James. 1995. Social Development. California : British Library Cataloguing In Publicaton.

Oentarto S M, Suwandi I M, Riyadmadji D. 2004. Menggagas Format Otonomi Daerah Masa Depan. Jakarta: Samitra Media Utama.

Priyono E. 2002. Situasi ketenagakerjaan Sumedang dan tinjauan kritis. Jurnal Analisis Sosial. (7)1: $1-15$. 